\title{
Tinjauan Kriminologis Budaya Nusa Tenggara Barat Tradisi Kawin Tangkap (Piti Rambang)
}

\section{Criminological Review of West Nusa Tenggara Culture Marriage Tradition (Piti Rambang)}

\author{
Astrid Budi Ati \\ Astridbudiati23@gmail.com
}

Abstrak: $\quad$ Tradisi piti rambang di Nusa Tenggara Barat dilakukan dengan cara mengambil paksa perempuan yang disukai oleh laki-laki yang akan dinikahkan saat perempuan tersebut tiba di kediaman laki-laki. Namun, praktek tersebut merugikan perempuan karena dirinya dapat dikategorikan sebagai korban penculikan. Hal ini dikarenakan perempuan yang menjadai palaingindi mawini (yang dibawa lari) tidak diberikan kesempatan untuk menetukan kepada siapa dia akan menikah. $\mathrm{Hal}$ ini membuat perempuan tertindas dan tida jarang kawin tangkap disertai dengan kekerasan. Meskipun tradisi ini didekriminalisasi oleh masyarakat, tapi tetap saja berdasarkan hukum pidana Indonesia tindakan tersebut termasuk tindak pidana dan pelaku dapat dihukum sesuai pasa yang berlaku.

Kata Kunci: Perempuan; kawing tangkap; tradisi

Abstract: The piti rambang tradition in West Nusa Tenggara is carried out by forcibly taking a woman who is liked by a man who will be married off when the woman arrives at the man's residence. However, this practice is detrimental to women because they can be categorized as kidnap victims. This is because the woman who is the palaingindi mawini (who is taken away) is not given the opportunity to decide whom she will marry. This makes women oppressed and often marry and capture accompanied by violence. Although this tradition is decriminalized by the community, still based on Indonesian criminal law, these actions are criminal acts and the perpetrators can be punished according to the applicable law.

Keywords: Woman; forced marriage; tradition 


\section{PENDAHULUAN}

Indonesia adalah negara yang masyarakatnya sangat beragam mulai dari suku, bahasa, dan agama. Terdapat banyak sekali suku bangsa di Indonesia yang setiap sukunya memiliki ciri khas yang berbeda-beda. Seperti data dari Badan Pusat Statistik (BPS) menyatakan terdapat 31 kelompok suku bangsa, yang mana tiap kelompok suku bangsa tersebut memiliki puluhan hingga ratusan suku bangsa (Na'im \& Syaputra, 2010). Dapat dikatakan bahwa struktur sosial banga Indonesia menunjukkan struktur bangsa yang majemuk. Gambaran ini menunjukkan bahwa semboyan Indonesia yaitu "Bhinneka Tunggal Ika" masih tetap terjaga dan terpelihara dengan baik (Na'im \& Syaputra, 2010).

Dalam pengertian yang paling umum, budaya mengacu pada sesuatu yang diwariskan secara sosial dari karakteristik pembelajaran masyarakat manusia (Kuper \& Kuper, 2005). Budaya menurut penggunaan ilmu sosial, berasal dari bahasa Latin cultura, dari kata kerja colere yang berarti 'untuk merawat atau mengolah'. Dalam ilmu sosial, istilah budaya maknanya adalah model dunia yang menggambarkan hubungan antara masyarakat, budaya, dan antar individu (Kuper \& Kuper, 2005). Tidak jarang, setiap budaya memiliki nilai dan norma masyarakat yang berbeda bahkan saling bertentangan.

Norma memiliki dua jenis pengertian. Norma jenis pertama mengacu pada tindakan yang umum atau khas (Kuper \& Kuper, 2005). Norma menggambarkan apa yang dilakukan kebanyakan orang (disebut norma deskriptif). Pengertian kedua dalah norma yang mengacu pada harapan bersama dalam masyarakat, organisasi atau kelompok tentang apa yang merupakan perilaku yang diinginkan atau disetujui untuk dijalani (Kuper \& Kuper, 2005). Norma seperti itu mencerminkan apa yang disetujui atau tidak disetujui kebanyakan orang. Norma ini memotivasi perilaku suatu kelompok dengan menjanjikan penghargaan atau hukuman sosial informal (Kuper \& Kuper, 2005). Apabila suatu kelompok suku bangsa memiliki norma yang berbeda dengan norma suku bangsa yang lain, atau bertentangan dengan norma negara Indoneisa maka akan menciptakan suatu konflik. Konflik ini adalah masalah bagi Indonesia yang memiliki banyak sekali kelompok suku bangsa.

\section{Patriarki}

Patriarki (secara harfiah berarti aturan ayah) adalah istilah yang telah digunakan secara luas dalam berbagai catatan kontras yang berusaha menggambarkan atau menjelaskan kondisi superioritas laki-laki atas perempuan (Kuper \& Kuper, 2005). Engels melihat posisi sosial 
wanita, tidak seperti pria, yang terstruktur oleh sifat fisik mereka (Kuper \& Kuper, 2005). Struktur nilai-nilai patriarki, yaitu hubungan antara jenis kelamin dan ketidaksetaraan gender ini menjadi paradigmatik dari semua ketidaksetaraan sosial lainnya.

Teori-teori yang berasal dari pemikiran feminis berpendapat bahwa kekerasan (pemukulan) mencerminkan kekuasaan dan kendali lakilaki atas perempuan (Dressler, 2002). Kekerasan terjadi berdasarkan variabel yang terstruktur secara sosial seperti ketidaksetaraan, patriarki, atau norma budaya (Dressler, 2002). Patriarki dipandang mengarah pada subordinasi perempuan dan menyebabkan pola historis kekerasan sistematis terhadap perempuan (Dressler, 2002). Semua varian teori feminis cenderung memiliki tiga asumsi utama (Kuper \& Kuper, 2005), yaitu:

(1) Gender adalah konstruksi sosial yang lebih menindas perempuan daripada laki-laki.

(2) Patriarki (dominasi laki-laki atas institusi sosial) membentuk konstruksi ini.

(3) Pengetahuan pengalaman wanita paling baik membantu kita membayangkan masyarakat non-seksis di masa depan.

\section{Penculikan}

Penculikan adalah tindak pidana yang dikenal luas yang dapat digambarkan sebagai perampasan dan penculikan orang lain yang bertentangan dengan keinginannya (Dressler, 2002). Dalam praktiknya, penculikan dapat terjadi baik dengan penggunaan kekerasan atau dengan penipuan atau bujukan. Undang-undang penculikan menghukum pengambilan atau pengekangan yang melanggar hukum baik anak di bawah umur maupun orang dewasa (Dressler, 2002). Hukum penculikan dapat digunakan bahkan jika pengekangan cukup substansial untuk mengganggu kebebasan korban, pelaku akan dihukum berdasarkan sebagian besar undang-undang penculikan (Dressler, 2002). Pengekangan yang terjadi bahkan di rumah korban sendiri telah dianggap sebagai penculikan di mana penyelamatan korban tidak mungkin (Wyoming, 1922). Penyekapan/penculikan di Indonesia diatur pada Pasal 318 Kitab Undang-Undang Hukum Pidana (KUHP) yang berbunyi "Barang siapa membawa pergi seorang dari tempat kediamannya atau tempat tinggalnya sementara dengan maksud untuk menempatkan orang itu secara melawan hukum di bawah kekuasaannya atau kekuasaan orang lain, atau untuk menempatkan dia dalam keadaan sengsara, diancam karena penculikan dengan pidana penjara paling lama dua belas tahun."

\section{Conflict of Conduct Norm}


Suatu sistem budaya dapat tidak teratur dalam arti bahwa ada konflik antara nilai, norma dan kepercayaan dalam budaya dominan yang dimiliki bersama secara luas (Yinger, 1960; Arsovska \& Verduyn, 2007). Thorsten Sellin (1938; Arsovska \& Verduyn, 2007) menjelaskan hubungan antara norma-norma sosial dan hukum, yang dalam pandangannya, urbanisasi yang pesat telah menempatkannya dalam keadaan konflik. Bagi Sellin (1938; Arsovska \& Verduyn, 2007), hukum merupakan perwujudan struktur normatif dari kelompok budaya / etnis yang dominan. Hukum pidana memuat norma-norma kejahatan yang sebagian besar mencerminkan nilai-nilai kelompok yang berhasil menguasai proses legislasi. Sebaliknya, norma perilaku yang mencerminkan nilai-nilai sosial budaya kelompok lain, kelompok yang kurang berpengaruh sering kali berbenturan dengan norma yang mengatur (Arsovska \& Verduyn, 2007). Oleh karena itu, konflik norma perilaku muncul sebagai akibat dari proses diferensiasi kelompok dalam suatu sistem budaya, atau sebagai akibat dari kontak antar norma yang diambil dari sistem budaya yang berbeda. Apabila norma hukum dari satu kelompok diperluas ke wilayah yang sebelumnya tidak menyadarinya, perluasan semacam itu dapat menyebabkan kebingungan dan pelanggaran norma-norma oleh orangorang yang tinggal di wilayah sasaran (Sellin 1938).

Conflict of conduct norm muncul karena kelompok-kelompok sosial di dunia ini yang memiliki kompleksitas norma-norma perilaku yang, karena perbedaan cara hidup dan nilai-nilai sosial yang dikembangkan oleh kelompok-kelompok ini, tampak membedakan mereka dari kelompok lain dalam banyak hal (Sellin, 1970). Perilaku anggota kelompok yang terlibat dalam konflik kode ini dalam beberapa hal dinilai tidak normal oleh kelompok lain. Menurut Sellin (1970) Conflict of conduct norm dapat terjadi:

(1) Ketika norma ini berbenturan di batas wilayah budaya yang berdekatan

(2) Ketika suatu kelompok budaya diperluas untuk mencakup wilayah kelompok budaya lain. Hal ini seperti halnya dengan norma hukum suatu negara.

Ketika anggota satu kelompok budaya bermigrasi ke kelompok budaya lain.

\section{METODE}

Dalam penelitian ini penulis menggunakan data sekunder dan menggunakan tinjauan literature sari berbagai sumber yang kredibel. Teknik penegumpulan data dilakukan selama beberapa hari untuk mencari sumber yang lengkap berasal dari artikel jurnal, surat kabar daring, dan beberapa video dari media sosial. Terdapat babarapa konsep yang 
digunakan dalam penleitian ini yaitu patriarki, penculikan, dan conflict of conduct norm. Pertanyaan penelitian yang ingin dijawab adalah : Bagaimana tradisi kawin tangkap (piti rambang) di Sumba dilihat berdasarkan perspektif Kriminologi melalui Conflict of Conduct Norm milik T. Sellin?

\section{HASIL DAN PEMBAHASAN}

\section{Uraian Data}

Oe H. Kapita, seorang antropolog yang menulis buku "Masyarakat Sumba dan Adat Istiadatnya" merekam sejumlah cara peminangan dalam masyarakat Sumba. Hal ini disebut sebagai piti maranggangu (ambil dalam perjumpaan) dan piti rambang (ambil paksa) atau dikenal umum sebagai 'kawin tangkap'. Akan tetapi istilah ini dipermasalahkan oleh masyarakat Sumba. Mereka mengklaim bahwa tradisi 'kawin tangkap' di Sumba memiliki proses adat yang jelas, bukan asal membawa perempuan secara paksa (VOAlndonesia, 2020). Sehingga istilah yang dibuat sebagai "kawin tangkap" akan menjadikan budaya ini sebagai sesuatu yang negatif di mata orang luar (VOAlndonesia, 2020).

Menurut dua pemuka adat Sumba dalam video yang diunggah oleh Keban di akun YouTubenya, mereka menyatakan dengan lengkap bagaimana prosedur yang dilakukan dalam "Kawin Tangkap” ini. Lebih baiknya prosedur dilakukan dengan adanya persetujuan antara orang tua laki-laki dan perempuan (Keban, 2020). Akan tetapi jika orang tua perempuan tidak sepakat, maka pihak laki-laki terpaksa untuk mengambil paksa anak perempuannya dengan cara diculik. Hal ini dibolehkan oleh budaya setempat. Setelah anak perempuan diambil paksa dan jika kemudian pihak perempuan datang maka akan melakukan musyawarah bersama (Keban, 2020). Musyawarah ini dilakukan dengan menawarkan belis berupa kuda, kerbau, dan parang sampai orang tua perempuan 
menyetujuinya. Apabila masih tidak setuju juga, pihak laki-laki terus menerus menawarkan belis bahkan sampai puluhan ekor kuda dan kerbau (Keban, 2020). Hal terpenting disini adalah bagaimana membangun komunikasi supaya mencapai kesepakatan. Akan tetapi dalam prakteknya sering terjadi pertangkaran apabila keluarga perempuan tetap tidak setuju untuk menikahkan anaknya dengan pihak laki-laki (Keban, 2020).

Apabila memang tidak bisa untuk menikah maka belis bisa dibatalkan. Akan tetapi jika pihak laki-laki tidak memberi kesempatan pada perempuan untuk pergi, maka perempuan tersebut tidak boleh pergi (Keban, 2020). Sering terjadi penolakan oleh anak perempuan dan jika perempuan tidak mau maka boleh dilepaskan. Tapi kemungkinan perempuan dilepaskan dan kembali ke kehidupan normalnya sangat kecil (Keban, 2020). Hal ini disebabkan oleh karena menurut budaya Sumba sebenarnya perempuan yang ditangkap merupakan perempuan terpilih dan akan diberikan belis yang besar dibandingkan dengan pernikahan pada umumnya.

Budaya atau tradisi itu tidak statis tetapi dinamis. Seorang perempuan Sumba Tengah mengatakan bahwa 'kawin tangkap' adalah tradisi turun menurun, namun praktiknya sudah berbeda dari yang dulu (DetikNews, 2020). Kawin tangkap memang ada dalam kebudayaan setempat, namun pelaksanaannya tidak bisa sembarangan dan terkait dengan ajaran Marapu. Agama Marapu ialah sistem keyakinan yang berdasarkan kepada pemujaan arwah-arwah leluhur (Soeriadiredja, 2013). Secara garis besar, calon mempelai laki-laki akan 'menangkap' calon mempelai perempuan, dalam proses yang sebetulnya sudah direncanakan dan disetujui oleh keluarga kedua belah pihak (VOAlndonesia, 2020). Apabila di dalam acara ini mereka mendapati ada restu dari pihak Marapu, mereka akan lakukan itu. Akan tetapi, jika seandainya ada 
penolakan mereka temukan pada tanda tertentu maka mereka juga tidak akan pernah memaksakan diri untuk mempraktikan kawin tangkap ini (VOAIndonesia, 2020).

Perempuan yang menjalankan tradisi itu atau yang disebut dalam bahasa daerahnya Palaingidi Mawini, dihargai pada masa lalu (DetikNews, 2020). Dulu orang yang menjalankan praktik kawin tangkap harus berasal dari keluarga kaya karena belis atau mahar yang harus dibayarkan ke pihak perempuan besar (DetikNews, 2020). Dulu, perempuan yang akan 'ditangkap' juga sudah dipersiapkan, didandani dengan pakaian adat lengkap dengan aksesoris gelang gading dan aneka perhiasan. Pria yang akan menikahi perempuan itu pun mengenakan pakaian adat lengkap dan menunggang kuda berhias kain adat. Setelah perempuan 'ditangkap', pihak laki-laki akan mengirim utusan ke keluarga perempuan untuk menyampaikan informasi mengenai kejadian kawin tangkap tersebut. Namun, praktik kawin tangkap sekarang ini lebih mengarah pada penculikan dan membuat kaum perempuan Sumba, khususnya di Sumba Tengah, Sumba Barat, dan Sumba Barat Daya, hidup dalam ketakutan (DetikNews, 2020).

Salah satu korban dari kawin tangkap ini menceritakan pengalamannya kepada jurnalis BBC. Korban ditangkap tanpa pengetahuan dan persetujuan dirinya. Setelah ditangkap ia dimasukkan kedalam mobil dan dirinya ditahan oleh beberapa orang pria yang sengaja dilakukan supaya korban tidak memiliki kekuatan melepaskan diri (BBC, 2020). Sesampainya di rumah pelaku, sudah banyak orang berkumpul disana, kemudian terdapat suara pukulan gong, dan menjalankan ritual yang sering terjadi ketika orang Sumba melakukan kawin tangkap (BBC, 2020). Saat prosesi tersebut terdapat ritual yang dilakukan untuk menenangkan perempuan yang menjadi palaingidi mawini. Ritual 
tersebut adalah ritual siram air ke kening perempuan yang akan dinikahi (BBC, 2020). Ritual ini dilakukan saat perempuan tiba di dalam rumah laki-laki dan apabila sudah disiram air, perempuan tersebut tidak bisa kembali atau lari dari rumah tersebut. Kemudian jika korban tersebut menolak dinikahi dan terus-menerus mengatakan "tidak" ia akan diberikan air minum dan nasi. Bagi orang Sumba istilah magic masih sering dipakai terutama pada saat tradisi kawin tangkap ini berlangsung. Air dan nasi yang diberikan pihak laki-laki kepada korban digunakan sebagai media sihir, jika perempuan tersebut meminum atau memakan nasi tersebut maka ia akan langsung mengatakan “iya” setuju atas pernikahannya (BBC, 2020).

\section{Analisis}

Piti Rambang atau kawin tangkap adalah tradisi yang dilegalkan oleh masyarakat Sumba sejak zaman dahulu. Menurut ajaran Marapu proses kawin tangkap ini dapat dilakukan dengan persetujuan orang tua pihak laki-laki dan perempuan. Perempuan yang menjadi palaingidi mawini adalah perempuan yang dihargai pada masa lalu karena pihak laki-laki yang akan menikahinya berasal dari keluarga kaya dan akan memberikan belis sangat besar. Sebelum dijemput, perempuan yang akan 'ditangkap' akan didandani dengan pakaian adat lengkap dengan aksesoris gelang gading dan aneka perhiasan. Namun, praktik kawin tangkap sekarang ini lebih mengarah pada penculikan dan membuat kaum perempuan Sumba hidup dalam ketakutan (DetikNews, 2020).

Kawin tangkap apabila dilihat dari prakteknya dapat tergolong sebagai penculikan karena dilakukan tanpa persetujuan perempuan. Seperti definisi penculikan dalam Dressler (2002), penculikan adalah tindak pidana yang dikenal luas yang dapat digambarkan sebagai 
perampasan dan penculikan orang lain yang bertentangan dengan keinginannya. Dalam praktiknya, penculikan dapat terjadi baik dengan penggunaan kekerasan atau dengan penipuan atau bujukan. Sebelum maupun sesudah adanya perubahan praktek dalam kawin tangkap, duaduanya dilakukan tanpa persetujuan perempuan dan berakhir dengan paksaan.

Conflict of conduct norm muncul karena kelompok-kelompok sosial memiliki kompleksitas norma-norma perilaku yang karena perbedaan cara hidup dan nilai-nilai sosial yang dikembangkan oleh kelompok-kelompok ini (Sellin, 1970). Pada kasus ini conflict of conduct norm terjadi karena suatu kelompok budaya diperluas sampai mencakup wilayah kelompok budaya lain (Sellin, 1970). Pada kasus "kawin tangkap” ini terjadi terjadi benturan antara norma adat Sumba dengan norma hukum negara Indonesia. Sebelum maupun sesudah adanya perubahan praktek dalam kawin tangkap, dua-duanya sama menyimpang.

Konflik norma perilaku muncul sebagai akibat dari proses diferensiasi kelompok dalam suatu sistem budaya, atau sebagai akibat dari kontak antar norma yang diambil dari sistem budaya yang berbeda. Apabila norma hukum dari satu kelompok diperluas ke wilayah yang sebelumnya tidak menyadarinya, perluasan semacam itu dapat menyebabkan kebingungan dan pelanggaran norma-norma oleh orangorang yang tinggal di wilayah sasaran (Sellin, 1938). Hukum pidana di Indonesia melarang praktek penculikan, akan tetapi dalam konteks budaya Sumba tradisi kawin culik adalah prosesi pernikahan yang sah. Hal ini membuat suatu kebingungan bagi masyarakat Sumba dan aparat penegak hukum di Sumba. 
Dalam norma hukum Indonesia yang mengkaji peraturan negaranya melalui Kitab Undang-undang Hukum Pidana (KUHP), kawin tangkap tergolong dalam tindakan penculikan. Hukum merupakan perwujudan struktur normatif dari kelompok budaya/ etnis yang dominan (Sellin, 1938; Arsovska \& Verduyn, 2007). Dalam KUHP pasal 332 ayat (1) yang berbunyi "bersalah melarikan wanita diancam dengan pidana penjara [2] paling lama sembilan tahun, barang siapa membawa pergi seorang wanita dengan tipu muslihat, kekerasan atau ancaman kekerasan, dengan maksud untuk memastikan penguasaannya terhadap wanita itu, baik di dalam maupun di luar perkawinan." Dengan ini, seharusnya para pelaku kawin tangkap dapat dijerat hukuman penjara sesuai dengan ketentuan tersebut.

Apabila dikaitkan dengan patriarki, kawin tangkap merupakan suatu tradisi yang dibentuk oleh patriarki. Patriarki mengarah pada subordinasi perempuan dan menyebabkan pola historis kekerasan sistematis terhadap perempuan (Dressler, 2002). Kawin tangkap memposisikan perempuan sebagai pihak yang berada lebih rendah dari laki-laki, ini dapat dilihat bahwa perempuan tidak memiliki hak untuk memilih laki-laki mana yang akan ia nikahi. Hanya pihak laki-laki saja yang diperhatikan dalam proses kawin tangkap ini. Tentu saja, tradisi kawin tangkap sangat menindas perempuan dan menggambarkan superioritas laki-laki terhadap perempuan.

\section{Reaksi Masyarkat}

Dr. Arianti Restianti Hunga sebagai seorang ahli Sosiologi Agama Universitas Kristen Satya Wacana (UKSW) Salatiga, berpendapat bahwa apapun sebutannya tidak menjadi permasalahan yang besar, karena inti dari budaya ini adalah ada pemaksaan atas nama birahi dari seseorang 
(VOAlndonesia, 2020). Dalam peristiwa ini sebagai bentuk kekerasan terhadap perempuan dan anak dengan mengatasnamakan budaya (Kompas, 2020). la mengatakan bahwa praktik kawin tangkap ini ditopang oleh budaya patriarki yang kental, kemiskinan, serta tidak meratanya pembangunan (VOAlndonesia, 2020). Peristiwa ini menunjukan betapa perempuan Sumba sendiri tidak mengerti transaksi yang terkait dengan tubuhnya (VOAIndonesia, 2020). Kawin tangkap tidak ada hubungannya dengan budaya, karena sebuah budaya pasti memiliki nilai dan unsur kemanusiaan.

Selama ini tidak ada laporan atas praktik ini, dikhawatirkan jangan-jangan korban tidak ingin dan tidak bisa melapor karena takut dengan ancaman kekerasan yang akan dihadapi (KEMENPPPA, 2020). Untuk itu, butuh respon aktif dari kepolisian. Data sudah ada dari empat wilayah (Sumba Tengah, Sumba Timur, Sumba Barat Daya, dan Sumba Barat) dan korban berusia antara 16-26 tahun (KEMENPPPA, 2020). Kawin tangkap ini hampir tidak pernah ada penyelesaian secara hukum. Persoalan yang kerap terjadi adalah penyelesaian melalui mediasi antar keluarga korban dan pelaku. Para akademisi menilai kasus yang hanya berakhir pada tingkat mediasi yang belum tentu memberikan solusi bagi korban tidak bisa dibiarkan begitu saja (KEMENPPPA, 2020).

Sejumlah pegiat perempuan mendorong pemerintah daerah untuk tegas menanggapi praktik 'kawin tangkap'. Alasannya, hal itu dianggap sebagai bentuk ketidakadilan yang berlapis bagi perempuan dan juga menimbulkan stigma bagi korban yang berhasil keluar dari penculikan (Kompas, 2020). Adapun pengamat budaya mengatakan hingga kini perdebatan terus berlanjut terkait asal-usul praktik tersebut. Ketidaktegasan untuk menghentikannya juga dianggap sebagai pemicu kejadian itu terus berulang (Kompas, 2020). 
Perempuan diculik di rumah tetangganya, di pinggir jalan di pasar, dan tempat-tempat umum lain. Kawin tangkap di Sumba itu tidak hanya terjadi pada perempuan cukup umur, tetapi juga pada anak, karena memang tidak pernah tahu perempuan-perempuan itu usianya berapa saat diculik (Kumparan, 2020). Terjadinya kesepakatan nikah antar orangtua kedua belah pihak tanpa ada persetujuan sang anak saja itu sudah melanggar hukum, apalagi ini dilakukan tanpa ada persetujuan antara orangtua dan si perempuan yang diculik (Kumparan, 2020).

Berdasarkan video yang diunggah oleh Tanesib (2020) di akun YouTube milikinya, ia mewawancarai sejumlah perempuan dewasa Sumba untuk dimintai pendapat tentang praktek "Kawin Tangkap". Menurut narasumber pertama ia menyatakan bahwa kawin tangkap ini dilakukan tanpa pengetahuan perempuan. Semasa kecil ia pernah menyaksikan langsung seorang perempuan yang menjadi korban kawin tangkap yang ditangkap dipinggir jalan dan langsung dimasukkan e dalam mobil pick up (Tanesib, 2020). Kemudian narasumber lain juga menceritakan bahwa tetangganya pernah menjadi korban kawin tangkap dan ia di tangkap di Pasar saat ia dimintai tolong untuk berbelanja kebutuhan rumah. Para narasumber ini menyatakan bahwa mereka tidak mau menjadi korban kawin tangkap (Tanesib, 2020). Mereka ingin menikahi seseorang yang benar-benar mereka cintai tanpa paksaan. Sebenarnya banak masyarakat juga sudah melarang tradisi ini, akan tetapi masih saja dilakukan oleh orang Sumba (Tanesib, 2020). Kawin tangkap itu adalah hal yang fatal itu pemaksaan bagi para perempuan, para narasumber tidak setuju karena mereka menganggap bahwa tradisi ini berarti melawan kehendak tuhan.

Selain masyarakat yang menentang adanya praktek tradisi kawin tangkap ini, ada juga masyarakat yang menganggap bahwa tradisi ini sahsah saja. Menurut dua pemuka adat Sumba kawin tangkap adalah tradisi yang sudah lama dilakukan oleh nenek moyang dan legal (Keban, 2020). 
Menurut mereka, kawin tangkap adalah tradisi yang seharusnya apabila seorang perempuan menjadi target kawin tangkap ia merasa terhormat. Hal itu karena dirinya akan diberikan belis yang sangat tinggi dibandingkan dengan proses pernikahan pada umumnya. Mereka juga menganggap pada saat proses kawin tangkap ini berlangsung, keluarga kedua belah pihak akan bermusyawarah sehingga tidak ada yang dirugikan. Apabila dilihat dari unggah warganet di sosial media, dapat diketahui bahwa tradisi kawin tangkap ini masih dilakukan oleh orang Sumba.

\section{PENUTUP}

Tradisi piti rambang dilakukan dengan cara mengambil paksa perempuan yang disukai oleh seorang laki-laki dan akan dinikahkan saat perempuan tersebut tiba di kediaman laki-laki. Tradisi ini memang sudah lama dilakukan oleh orang Sumba dan legal pada zaman dahulu, akan tetapi prakteknya dizaman sekarang lebih mengarah ke penculikan. Namun, sebelum dan sesudah praktek tersebut berubah keduanya tetap saja merugikan perempuan korban. Hal ini dikarenakan perempuan yang menjadi palaingidi mawini tidak diberikan kesempatan untuk menentukan kepada siapa dirinya akan menikah. Hal ini membuat perempuan tertindas dan tidak jarang kawin tangkap disertai dengan kekerasan. Hukum pidana di Indonesia melarang praktek penculikan, akan tetapi dalam konteks budaya Sumba tradisi kawin culik adalah prosesi pernikahan yang sah. Hal ini membuat suatu kebingungan bagi masyarakat Sumba dan aparat penegak hukum di Sumba. Tetap saja, seharusnya tradisi kawin tangkap ini dihentikan karena menindas perempuan. 


\section{DAFTAR PUSTAKA}

Jurnal

Arsovska, J., \& Verduyn, P. (2007). Globalization, Conduct Norms and 'Culture Conflict': Perceptions of violence and crime in an ethnic albanian context. British Journal of Criminology, 48(2), 226-246

Sellin, T. (1970). "The Conflict of Conduct Norms", in M.E. Wolfgang et.al. The sociology of Crime and Delinquency. 2nd Ed. New York: John Wiley and Sons, Inc. pp. 186-189.

Soeriadiredja, Purwadi. (2013). Marapu: Konstruksi Identitas Budaya Orang Sumba, NTT. Antropologi Indonesia, 34 (1), 59-73

Buku

Dressler, J. (2002). Encyclopedia of Crime and Justice, Second Edition. New York: Macmillan Reference.

Na'im, A. \& Syaputra, H. (2010). Kewarganegaraan, Suku Bangsa, Agam, dan Bahasa Sehati-hari Penduduk Indonesia: Hasil Sensus Penduduk 2010. Badan Pusat Statistik: Jakarta

Kuper, A, \& Kuper, J. (2005). The Social Scince Encyclopedia, Second Edition. London: Routledge

Peraturan Perundang-undangan

Kitab Undang-undang Hukum Pidana( KUHP)

Internet

FloresPedia.com. (2020, Juli 1). Polda NTT Terima 1 Laporan Khusus Penculikan Perempuan dengan Modus Kawin Tangkap. Dipetik pada 31 Desember 2020 dari Kumparan: https: / / kumparan.com/florespedia/polda-ntt-terima-1-laporankasus-penculikan-perempuan-dengan-modus-kawin-tangkap1 tidMjslqS4/full

Keban. [Keban Vlog]. (2020, Juli 17). Kawin Tangkap Itu Bukan Kejahatan Budaya Kawin Tangkap Budaya Sumba Tokoh Masyarakat Bicara [Video]. You Tube. https:/ / www.youtube.com/watch?v=Jlwh6n9oR70

KEMENPPPA. (2020, Juni 26). Menteri PPPA: Dalih Tradisi Budaya Jangan Dipakai sebagai Kedok untuk Melecehkan Perempuan dan Anak. Dipetik pada 31 Desember 2020 dari Kemenpppa.go.id: https://kemenpppa.go.id/index.php/page/read/29/2744/menteri 
-pppa-dalih-tradisi-budaya-jangan-dipakai-sebagai-kedok-untukmelecehkan-perempuan-dan-anak

Detikcom. (2020, Juni 30). Menanti Pelaku Praktik 'Kawing Tangkap' di Sumba Terungkap. Dipetik pada 31 Desember 2020 dari DetikNews: https://news.detik.com/berita/d-5073545/menanti-pelakupraktik-kawin-tangkap-di-sumba-terungkap/2

Tanesib, M. [Medison Tanesib]. (2020, Agustus 11). Kawin Tangkap di mata Gadis Sumba di Rantauan [Video]. You Tube. https: / /www.youtube.com/watch?v=irOigmTYuKI

Tusikal, Rio. (2020, Juli 8). Apa yang Salah dari Tradisi ‘Kawin Tngkap’ di Sumba? Dipetik pada 31 Desember 2020 dari VOAlndonesia: https://www.voaindonesia.com/a/apa-yang-salah-dari-tradisikawin-tangkap-di-sumba-/5494289.html

Rachmawati. (2020, Juli 9). Kawin Tangkap di Sumba, Diculik untuk Dinikahi sampai Tenggorokan Kering. Dipetik pada 31 Desember 2020 dari Kompas: https://regional.kompas.com/read/2020/07/09/06070001/kawintangkap-di-sumba-diculik-untuk-dinikahi-citra-menangissampai?page $=$ all

Tambunan, L. (2020, Juli 8). Kawin Tangkap: Kisah Perempuan Diculik untuk Dinikahi di Sumba menangis sampai Tenggorokan Kering. Dipetik pada 5 januari 2021 dari BBCNews: https://www.bbc.com/indonesia/indonesia-53317050 


\section{LAMPIRAN}

- Cuitan yang berisikan Video Proses Kawin Tangkap https: / / twitter.com/Jong_Timor/status/1273769105061900289?ref src=twsrc\%5Etfw\%7Ctwcamp\%5Etweetembed\%7Ctwterm\%5E12737 69105061900289\%7Ctwgr\%5E\%7Ctwcon\%5Es1_\&ref_url=https\%3A\%2 F\%2Fwww.voaindonesia.com\%2Fa\%2Fapa-yang-salah-dari-tradisikawin-tangkap-di-sumba-\%2F5494289.html

- Pertikaian akibat Kawin Tangkap https://www.youtube.com/watch?v=8FH6mCWp_cs

- Pendapat Korban Kawin Tangkap https: / / www.youtube.com/watch?v=37SGu604f-0

- Video Proses Penangkapan pada saat Tradisi Kawing Tangkap Berlangsung https://www.youtube.com/watch?v=EMSLGhcyHR8

- Pendapat Perempuan Sumba terhadap Tradisi Kawin Tangkap https://www.youtube.com/watch?v=irOigmTYuKI

- Pernyataan Pemuka Adat terhadap Tradisi Kawin Tangkap https: / / www.youtube.com/watch?v=Jlwh6n9oR70 